\title{
FLUENCY AND ACCURACY LEVELS IN WRITING OF GRADE 12 ESL LEARNERS
}

Johann L. van der Walt \& Karien Hattingh

North-West University

This study investigated two aspects of the level of second language development achieved by Grade 12 English Second Language (ESL) learners in South Africa. It was inspired by the general concern about standards in the matriculation examination and calls for the improvement of ESL teaching and learning. The study involved an investigation and description of the fluency and accuracy levels of Grade 12 learners. We focussed on writing, since it is generally accepted that characteristic patterns of advanced learners are best studied in written production. 216 compositions were analysed in terms of T-units, and fluency and accuracy frequencies and ratios were calculated. Results show that fluency ratios $(W / T$ and $W / E F T)$ and an accuracy ratio (EFT/T) paint a poor picture of learners' performance in writing, and suggest that Grade 12 ESL learners are ill-prepared for tertiary study. Better control of morphology and syntax is required, as this will lead to a general improvement of fluency and accuracy levels in ESL.

\section{Keywords}

fluency; accuracy; English as a second language; writing; high school learners

\section{INTRODUCTION}

There seems to be a widespread concern about the standard of English Second Language in South African schools, and there have been numerous calls for the improvement of English teaching and learning. For example, in a reaction to matriculation results, the executive officer of the South African certification council, Umalusi, has called for a national strategy to be implemented in an attempt to improve standards of English. She stated that the challenge for schools to improve the national standard of English was even tougher than improving standards in Mathematics and Science (Beeld, 8 September, 2004). Some learners are virtually illiterate in the matriculation year (Beeld, 9 September 2004). The problem that we face is that learners emerge from secondary schools with deeply ingrained and very faulty interlanguages. 
Not much data from a developmental perspective are available on the level of development of learners of English as a second language (ESL) in South Africa. In theory, a Grade 12 learner should be at an advanced level after 12 years of learning English and, in the majority of schools, tuition through the medium of English. One would have to question, however, what 'advanced' means in the South African context. What level of syntactic development have Grade 12 ESL learners reached? How fluent and accurate are they in English syntax? The purpose of this article is to describe the fluency and accuracy levels of Grade 12 ESL learners from a Second Language Acquisition perspective. We focus on writing only, as it is generally accepted that the characteristic patterns of advanced learners are best studied in written production (Lorenz 1999: 11).

\section{INTERLANGUAGE AND LEVELS OF DEVELOPMENT}

It is now generally accepted that the second language learner possesses a 'built-in' syllabus, or an internal programmed sequence for learning different aspects of the target language (Gass \& Selinker, 2001: 112). Second language development is regarded as consisting of a continually evolving system which takes the learner further from the source system (L1) and closer to the target system (L2). These learner-based systems process input from the target language in small processable doses, and form an interlanguage which is somewhere between the learner's L1 and the target language. Learners pass through stages en route to the target language rule, and thus follow a developmental pattern of acquisition (Ellis 1994: 73; SavilleTroike, 2006: 44). They reach a particular stage or level of acquisition before moving on to the next level.

While few learners achieve native-like proficiency (many merely fossilise at a particular level and do not progress any further), every learner reaches a certain level in the developmental continuum. This is often referred to in terms such as intermediate, upper-intermediate and advanced. Harmer (2004: 44) says that the problem with these labels is that they mean different things to different people, as there are no standard definitions of them. It is especially difficult to define what the advanced level means. The advanced learner should be able to function most of the time at sentence level (i.e. his interlanguage is more developed than that of the intermediate student, who still has to exercise most of his choices at word or even morpheme level because his knowledge of the grammar cannot be recalled automatically). Learners are able to handle larger units successfully only after automatising the rules and restrictions governing smaller units.

In this article we report on Grade 12 ESL learners' development in English and determine their collective level of syntactic development.

\section{FLUENCY AND ACCURACY IN WRITING}

Learners' interlanguage development can be expressed in terms of their levels of fluency and accuracy in the second language (Fulcher \& Davidson, 2007: 8). Both fluency and accuracy 
are essential measures in the assessment of a learner's proficiency in a second language, and are core criteria used in rating scales (cf. Fulcher, 2003; Hawkey \& Barker, 2004).

Fluency is difficult to define, although it is a common term in language teaching and testing and has been in use for a long time (Fulcher \& Davidson, 2007: 7). Fillmore (1979: 93) identifies four different kinds of fluency: the ability to produce language rapidly; coherently and densely; appropriately; and creatively. He states that 'the maximally gifted wielder of language is somebody who has all these abilities'. Brumfit (1984: 54) points out that, with the exception of the first, they all require capacities that we recognise in people who are not linguistically fluent. The first quality, rapidity, refers to the quantity of production, which in terms of the present discussion refers to the ability to write without significant pauses for an extended period. Lennon (1990: 387) adopts this narrow sense of fluency, and defines it as the rate and length of output. Wolfe-Quintero, Inagaki and Kim (1998: 14) adopt the same approach and state that fluency in writing means that more words and more structures are accessed in a limited time, whereas a lack of fluency means that only a few words or structures are accessed. Fluency is therefore a measure of the sheer number of words or structural units a writer is able to include in their writing within a particular period of time.

Accuracy in morpho-syntactic usage is a general requirement in language teaching, although there has been a tendency in recent years to neglect it because of the emphasis on communicative ability. Writing requires higher levels of accuracy than spoken language. Accuracy level depends on a learner's linguistic competence, i.e. the degree of accuracy of the language representation itself, the strength of interference from the L1 or earlier stages of L2 development, and the degree of automatization that has taken place. The goal is to produce as few errors as possible. Accuracy can therefore be defined as "freedom from error", or comparison with target-like language usage.

The above definitions are adopted for the purposes of this article.

\section{MEASURING FLUENCY AND ACCURACY IN WRITING}

Fluency and accuracy in writing can be measured by means of length and error (WolfeQuintero et al., 1998). This is based on a straightforward premise, viz. that learners with high proficiency would write longer pieces, with fewer errors, than less proficient ones. A central question in this regard is: which production unit should be analysed? The sentence is the obvious choice, but proves to be problematic in practice, as it is not always easy to identify it in second-language writing - learners often produce many ands, use run-on sentences, and do not make use of punctuation.

Gass and Selinker (2001: 50) suggest that the T-unit (originally proposed for the analysis of first language learning by Hunt in 1965) is a more precise measure of syntactic development in a language, and it has been used in a number of learner studies. It has also been used for the analysis of the language of students with learning disabilities (e.g. Englert \& Dunsmore, 2007). A T-unit consists of a main clause, together with any clauses that are attached to or embedded in the main clause. It is formally defined as "one main clause, plus any subordinate 
clauses or non-clausal structure that is attached to or embedded in it" (Hunt, 1970: 4). Each unit should be able to function as a complete grammatically correct sentence on its own if punctuated like a sentence (started with a capital letter and ended with a full stop). Gass and Selinker (2001: 50) illustrate the identification of T-units as follows:

- John woke up.

- John woke up, although he was tired.

- although he was tired.

The first two are T-units, while the third is not. The definition of a T-unit was adapted for use with non-native speakers by modifying its definition to incorporate the notion of error-free Tunits rather than just T-units (Gass \& Selinker, 2001: 50). The first language of the learner plays no role in T-unit analysis. It therefore does not discriminate on the basis of the native language. A large number of studies (cf. Wolfe-Quintero et al., 1998, for a review) since the 1970s have confirmed that it is a reliable measure of syntactic development in a second language, and it has been used to establish different levels of syntactic development. For example, students produce more error-free T-units as they develop, both orally and in writing. T-units are widely used because they are easy to identify and are relatively lowinference categories (Mackey \& Gass, 2005: 232). While T-unit analysis does not provide information on the discourse-functional aspects of learner writing, it provides important insights into their syntactic development (Grabe \& Kaplan, 1997: 46).

\section{METHOD OF RESEARCH}

A sample of 216 compositions produced by Grade 12 ESL learners from six South African provinces was analysed. (A number of compositions could not be analysed because they proved to be incomprehensible.) There were 112 Higher Grade and 104 Standard Grade compositions. The compositions were sent in for moderation to one of the authors after the matriculation examination in 2003. They were randomly selected by the provincial departments of education. Permission was obtained from these departments to analyse the language of the compositions for purposes of research. The six provinces were randomly selected from the nine ones. The compositions were written by learners from various first language backgrounds. They were required to write 250-300 words.

Compositions were coded and divided into one of five groups. The division was made according to the mark attributed to each essay by the marker. This mark was allocated in terms of both language and content. This is indicated in Table 1.

Table 1: Division of compositions

\begin{tabular}{|l|l|l|}
\hline Group & Category & $\%$ range \\
\hline 1 & Poor & $0-19$ \\
2 & Fair & $20-39$ \\
3 & Average & $40-59$ \\
4 & Good & $60-79$ \\
5 & Excellent & $80-100$ \\
\hline
\end{tabular}


The marks allocated varied from 0 to 39 out of 40 . The average mark was 19.43 out of 40 or $48.6 \%$. We infer that the progression reflected in Table 1 indicates degrees of proficiency in written English.

The compositions were analysed for length and error. We first divided them into T-units, and then distinguished between error-free and error T-units. Our focus was on grammatical accuracy only, and spelling and punctuation errors were ignored. Each T-unit was considered in its context when errors in it were determined. For example, pronouns had to be correct in the context of a paragraph. Two researchers conducted the analyses to ensure the reliability of the results, and very little variation between them was found. The following is an example of the analysis:

Being a single parent it good expeciolly when you are having Job. $\langle T\rangle$ You can enjoy that part $\langle T\rangle\langle E F T\rangle$ because you know that you do everything by yourself without asking for help. $\langle T\rangle\langle E F T\rangle$ Parent who are facing that situation can be a mother or a father, $\langle T\rangle$ they must tel themselves thay are not gonna let their children safer like that for their circumstances quencequences. $\langle T\rangle$ And again it can be difficult to other parent expesially when you are not working to much of a burden for them. $\langle T\rangle$ They are trying to do their best. $\langle T\rangle\langle E F T\rangle$

We used a number of measures to determine fluency and accuracy frequencies and ratios. They have all been confirmed as valid measures of development in a second language, as they correlate well with proficiency (cf. Wolfe-Quintero et al., 1998; Lee, 2005). Frequencies involve a count of a particular feature or unit, and (only) provide an overall picture of usage patterns. A ratio measure, in which the presence of one type of unit is divided by the total number of comparable units, is the best type of measure, as it contains a fixed delimiter. Ratios are used to measure the length of a given unit or the rate of accuracy within a given unit (Wolfe-Quintero et al., 1998: 10). The following calculations were done:

- Fluency frequencies: Average number of words per composition (W) and average number of T-Units (T);

- Fluency ratios: Average number of words per T-unit (W/T) and average number of words per Error-Free T-unit (W/EFT);

- Accuracy frequency: Average number of Error-Free T-units per composition (EFT);

- Accuracy ratio: Average number of Error-Free T-units per T-unit (EFT/T).

Analysis of Variance (ANOVA) tests (cf. Seliger \& Shohamy, 1989: 234-235; Hatch \& Farhady, 1982: 129) were conducted for each of the measures, followed by a multiple comparison using the method proposed by Tukey (cf. Miller, 1981: 37-48). Both these tests were conducted at a $5 \%$ level of significance.

\section{RESULTS: FLUENCY MEASURES}

The results of the fluency frequency measures are presented in Tables 2 and 3. Table 2 presents the results for the average composition length (W) for each group. 
Candidates who exceeded the required length mostly wrote between 350 and 410 words. One composition was exceptional - it was 815 words, written by a Standard Grade learner. The second longest essay, also a SG one, consisted of 572 words. The table shows a steady increase in length from Groups 1 to 3 and 5, with Group 4 showing a slight decrease. An analysis of variance test indicated that $\mathrm{F}(4 ; 211)=6.44$ with $\mathrm{p}<0.0001$. Table 2 also reports the results for the Tukey test comparing the mean lengths of compositions over the groups. Groups with the same superscript letters do not differ significantly. The mean length of compositions distinguishes Group 5 from all the other groups. Group 4 is not distinguished from Groups 3, 2 and 1. Groups 3 and 2 do not differ significantly, but Groups 2 and 3 are significantly different from Groups 1 and 5. Composition length generally gives an indication of whether one can expect a composition to be poor, average or very good, but there are exceptions to this.

Table 2: The average number of words per composition as calculated for groups

\begin{tabular}{|l|l|l|l|l|}
\hline Group & N & Mean length & Standard Deviation & Coefficient of Variance \\
\hline 1 & 29 & $222.14^{\mathrm{c}}$ & 88.33 & 39.76 \\
2 & 57 & $279.86^{\mathrm{b}}$ & 83.01 & 29.66 \\
3 & 64 & $287.25^{\mathrm{b}}$ & 97.2 & 33.84 \\
4 & 48 & $266.27^{\mathrm{bc}}$ & 56.88 & 21.36 \\
5 & 18 & $343.83^{\mathrm{a}}$ & 86.05 & 25.03 \\
\hline
\end{tabular}

Table 3 indicates the average number of T-units per composition (T) for the five groups.

Table 3: Average number of T-Units per composition

\begin{tabular}{|l|l|l|l|l|}
\hline Group & N & Mean & Standard Deviation & Coefficient of variance \\
\hline 1 & 29 & $23.76^{\mathrm{b}}$ & 9.06 & 38.14 \\
2 & 57 & $29.91^{\mathrm{ab}}$ & 10.18 & 34.04 \\
3 & 64 & $29.19^{\mathrm{ab}}$ & 9.80 & 33.58 \\
4 & 48 & $26.85^{\mathrm{ab}}$ & 7.28 & 27.09 \\
5 & 18 & $30.83^{\mathrm{a}}$ & 10.56 & 34.24 \\
\hline
\end{tabular}

There is an increasing trend for non-adjacent groups. There were no significant statistical differences between the groups for the number of T-units as shown by the results of the Tukey test. Only Groups 1 and 5 differ significantly.

Fluency ratios are indicated in Tables 4 and 5. Table 4 indicates the average number of words per T-unit (W/T) for the five groups. 
Table 4: Average number of words per T-unit as calculated for consecutive groups

\begin{tabular}{|l|l|l|l|l|}
\hline Group & N & Mean & Standard Deviation & Coefficient of Variance \\
\hline 1 & 29 & $9.64^{\mathrm{b}}$ & 2.62 & 27.20 \\
2 & 57 & $9.86^{\mathrm{b}}$ & 2.53 & 25.69 \\
3 & 64 & $10.18^{\mathrm{b}}$ & 2.54 & 24.92 \\
4 & 48 & $10.36^{\mathrm{b}}$ & 2.24 & 21.58 \\
5 & 18 & $11.85^{\mathrm{a}}$ & 3.70 & 31.18 \\
\hline
\end{tabular}

Although the results for the groups are closely clustered together, the average number of words per T-unit increases for each consecutive group. All five groups produced what Hunt (1965) refers to as mid-length T-units, and not full-length ones, with an average of 10.38. An analysis of variance test resulted in $\mathrm{F}(4 ; 211)=2.92$ with $\mathrm{p}<0.0224$. Tukey's Studentized Test was conducted in order to see whether any of the groups' results differed significantly. The mean length of T-units per composition distinguishes only Group 5 significantly from all the groups. Groups 1 to 4 do not differ significantly.

Table 5 reports the number of words per composition in error-free T-units (W/EFT).

Table 5: The number of words in EFTs as calculated for groups

\begin{tabular}{|l|l|l|l|l|}
\hline Group & $\mathrm{N}$ & Mean & Standard Deviation & Coefficient of Variance \\
\hline 1 & 29 & $6.19^{\mathrm{d}}$ & 3.43 & 55.45 \\
2 & 57 & $7.96^{\mathrm{cd}}$ & 2.99 & 37.59 \\
3 & 64 & $8.51^{\mathrm{bc}}$ & 2.05 & 24.03 \\
4 & 48 & $9.05^{\mathrm{b}}$ & 2.60 & 28.74 \\
5 & 18 & $10.76^{\mathrm{a}}$ & 2.89 & 26.86 \\
\hline
\end{tabular}

The average W/EFT was 8.49. An ANOVA resulted in $F(4 ; 211)=9.32$, which is statistically significant, with $\mathrm{p}<0.0001$. According to the results of the Tukey test, the number of words per error-free T-units discriminates well between Groups 1, 3 and 5, i.e. non-adjacent groups, but not between adjacent groups.

\section{DISCUSSION}

It is generally accepted that more developed learners write longer compositions (cf. LarsenFreeman \& Strom, 1977; Hawkey \& Barker, 2004). Learners who write longer compositions on average score higher marks. Learners who are more proficient are generally more selfconfident, show a better command of syntax and have a wider range of vocabulary and consequently write longer compositions. The results show a clear increase in the average number of words per composition for consecutive groups, with the exception of Group 4. The weakest group (Group 1) wrote an average of 222.14 words per essay, which is much shorter than was required. The averages of Groups 2 to 4 are within the required length; between 250 and 300 words per composition. Students in Group 5 wrote longer compositions than were required, with an average of 343.3 words per composition. 
The average T-unit length (W/T) is an important measure in both L1 and L2 acquisition. A number of studies (e.g. Larsen-Freeman, 1983; Homburg, 1984; Bardovi-Harlig \& Bofman, 1989) have shown that it is a good indicator of syntactic development. Academic writing on average contains 20 words per T-unit (Thompson, 2003). The average here of 10.38 words (Table 4) indicates that these Grade 12 learners are ill-prepared for tertiary study. Even the excellent group (Group 5), which can be expected to go on to university, falls far short of this norm. The words per error-free T-unit ratio (W/EFT) (Table 5), with an average of 8.49, indicates an increasing trend, ranging from 6.19 to 10.76 . This can only be regarded as an average achievement.

Table 6 provides a comparison of means on fluency measures of a number of studies dating back to the 1970s. A direct comparison of our data with the others is not possible, because length of exposure to and study of English differ greatly, but the table gives an indication of the relative fluency in writing of the different groups. The table indicates a general norm of 13 to 17 words per T-unit, and 9 to 13 words per error-free T-unit at advanced levels. The South African learners' performance of 10.39 and 8.49 respectively indicates a generally poor fluency performance.

\section{Table 6: Comparison of means on fluency measures}

\begin{tabular}{|l|l|l|l|l|}
\hline Study & Learners & Level & W/T & W/EFT \\
\hline Cooper 1976 & L1 English & Sophomores & 10.3 & \\
& Students learning & Juniors & 12.6 & \\
& German at university & Seniors & 15.2 & \\
& \& native speakers & Graduates & 16.9 & \\
& & Natives & 23.00 & \\
\hline Hirano 1991 & Japanese students & Low & 8.88 & 5.95 \\
& learning English & Mid & 10.00 & 7.64 \\
& at university & High & 12.64 & 9.38 \\
& at three levels & & & \\
\hline Ho-Peng 1983 & Various & Level 1 & 13.40 & 7.74 \\
& L1 groups & Level 2 & 16.26 & 13.64 \\
& learning English & Level 3 & 16.47 & 16.01 \\
& at university & & & \\
\hline Larsen-Freeman & Various & Level 1 & 12.02 & 4.61 \\
& L1 groups & Level 2 & 13.72 & 7.25 \\
& learning English & Level 3 & 15.23 & 9.26 \\
& at university & Level 4 & 15.25 & 10.77 \\
& & Level 5 & 15.67 & 13.20 \\
\hline Larsen-Freeman & Various & Level 2 & 13.73 & 8.36 \\
& L1 groups & Level 3 & 17.11 & 12.61 \\
& learning English at & Level 4 & 17.21 & 11.36 \\
& high intermediate level & & & \\
\hline Yau 1991 & Chinese & ESL Grade 9 & 10.82 & \\
& students learning & ESL Grade 13 & 15.54 & \\
& English at high school & & & \\
\hline Van der Walt \& & Grade & Group 1 & 9.64 & 6.19 \\
Hattingh & 12 ESL learners & Group 2 & 9.86 & 10.76 \\
& & Group 3 & 10.18 & \\
& & Group 4 & 10.36 & 11.85 \\
\hline
\end{tabular}

Per Linguam 2007 23(2):15-28 
While English is studied as a second language for twelve years and used as medium of instruction in the majority of our schools, the other learners referred to in the table studied a foreign language, to which they had limited exposure, and which they studied for a relatively short time. Our average of 10.39 words per T-unit does not compare well with Cooper's (1976) (admittedly dated) native speaker norm of 23 words per T-unit, or with the average of 20 words per T-unit for academic writing (Thompson, 2003).

\section{RESULTS: ACCURACY MEASURES}

Table 7 indicates the number of error-free T-units (EFTs) per composition.

Table 7: The number error-free $\mathbf{T}$-units per composition as calculated for each group

\begin{tabular}{|l|l|l|l|l|}
\hline Group & N & Mean & Standard Deviation & Coefficient of Variance \\
\hline 1 & 29 & 4.93 & 4.64 & 94.02 \\
2 & 57 & 9.84 & 6.39 & 64.97 \\
3 & 64 & 11.23 & 6.10 & 54.27 \\
4 & 48 & 13.69 & 6.78 & 49.53 \\
5 & 18 & 21.89 & 9.57 & 43.70 \\
\hline
\end{tabular}

The average EFTs is 12.32. There is a clear linear trend toward a higher number of error-free T-units. The table indicates that learners in Group 5 not only write longer T-units, but also do so with fewer errors. An analysis of variance test showed the results to be statistically significant with $\mathrm{F}(4 ; 211)=21,76$ and $\mathrm{p}<0.0001$.

An accuracy ratio (EFT/T) provides a good indication of the level of the syntactic development of Grade 12 learners (cf. Table 8).

Table 8: Accuracy ratio (EFT/T)

\begin{tabular}{|l|l|l|l|l|}
\hline Group & $\mathrm{N}$ & Ratio & Standard Deviation & Coefficient of Variance \\
\hline 1 & 29 & $.21^{\mathrm{d}}$ & 18.85 & 89.49 \\
2 & 57 & $.34^{\mathrm{c}}$ & 21.51 & 62.72 \\
3 & 64 & $.40^{\mathrm{bc}}$ & 18.04 & 45.00 \\
4 & 48 & $.51^{\mathrm{b}}$ & 22.24 & 43.56 \\
5 & 18 & $.70^{\mathrm{a}}$ & 12.04 & 17.26 \\
\hline
\end{tabular}

The average EFT/T is .43. The multiple comparisons of the Tukey test distinguished Group 5 from all the other groups. Groups 4 and 3 do not differ significantly. However, Groups 5, 3 and 1 are distinguished clearly. According to these results, the EFT ratio discriminates well between non-adjacent groups, but not between adjacent groups. 


\section{DISCUSSION}

Although length may be a satisfactory indicator of increasing proficiency, it alone is not a sufficient measure of L2 acquisition. Structural errors in language should also be taken into account, as they indicate a lack of syntactic control. Longer T-units tend to be more complex and learners can more readily produce errors. It is easier to make errors when writing longer, more complex structures than when writing short and simple ones. Results for the number of error-free T-units (EFTs) show an upward linear trend for consecutive groups, ranging from a very low 4.93 to a high of 21.89 , with an average of 12.32 . The error-free T-unit ratio (EFT/T) ranges from 0.21 to 0.7 (Table 8), with an average of .43. These data indicate the wide range of proficiencies in Grade 12 English Second Language, with some learners performing very poorly, and an average accuracy level which cannot be regarded as acceptable.

Table 9: Comparison of means on accuracy measures

\begin{tabular}{|c|c|c|c|c|}
\hline Study & Learners & Level & EFT & $\mathrm{EFT} / \mathrm{T}$ \\
\hline Hirano 1991 & $\begin{array}{l}\text { Japanese students } \\
\text { learning English } \\
\text { at university } \\
\text { at three levels }\end{array}$ & $\begin{array}{l}\text { Low } \\
\text { Mid } \\
\text { High }\end{array}$ & $\begin{array}{l}2.10 \\
3.88 \\
5.06\end{array}$ & $\begin{array}{l}.15 \\
.23 \\
.33\end{array}$ \\
\hline $\begin{array}{l}\text { Larsen-Freeman } \\
1978\end{array}$ & $\begin{array}{l}\text { Various } \\
\text { L1 groups } \\
\text { learning English } \\
\text { at university }\end{array}$ & $\begin{array}{l}\text { Level } 1 \\
\text { Level } 2 \\
\text { Level } 3 \\
\text { Level } 4 \\
\text { Level } 5 \\
\end{array}$ & & $\begin{array}{l}.11 \\
.19 \\
.22 \\
.34 \\
.50 \\
\end{array}$ \\
\hline $\begin{array}{l}\text { Larsen-Freeman } \\
1983\end{array}$ & $\begin{array}{l}\text { Various } \\
\text { L1 groups } \\
\text { learning English at } \\
\text { high inter-mediate } \\
\text { level } \\
\text { at university }\end{array}$ & $\begin{array}{l}\text { Level } 2 \\
\text { Level } 3 \\
\text { Level } 4\end{array}$ & & $\begin{array}{l}.42 \\
.43 \\
.38\end{array}$ \\
\hline Lee 2005 & $\begin{array}{l}\text { Various } \\
\text { L1 groups } \\
\text { learning Japanese } \\
\text { at university } \\
\text { \& native speakers }\end{array}$ & $\begin{array}{l}\text { Learners } \\
\text { Native } \\
\text { speakers }\end{array}$ & & $\begin{array}{l}.58 \\
.95\end{array}$ \\
\hline $\begin{array}{l}\text { Van der Walt \& } \\
\text { Hattingh }\end{array}$ & $\begin{array}{lll}\text { Grade } & 12 & \text { ESL } \\
\text { learners } & & \end{array}$ & $\begin{array}{l}\text { Group } 1 \\
\text { Group } 2 \\
\text { Group } 3 \\
\text { Group } 4 \\
\text { Group } 5\end{array}$ & $\begin{array}{l}4.93 \\
9.84 \\
11.23 \\
13.69 \\
21.89\end{array}$ & $\begin{array}{l}.21 \\
.34 \\
.40 \\
.50 \\
.70\end{array}$ \\
\hline
\end{tabular}

A direct comparison of means on accuracy measures with other studies is not possible, but Table 9 provides an indication of the relative accuracy levels of different groups that studied foreign (not second) languages at university. 
Little comparative data for EFTs are available, but South African learners do not seem to fare badly on this measure with an average of 12.32 when compared with Hirano's (1991) foreign language learning data. The general norm for EFT/T seems to be between 0.3 and 0.6; with our average .43 we are towards the lower end of the scale. Lee's (2005) native speaker norm of 0.95 for EFT/T indicates that our learners fall rather short, with the best ones achieving only 0.7 .

\section{CONCLUSION}

The results of the study are in line with expectations: learners of English as a second language at a higher level of syntactic development tend to write longer essays than those at lower levels; they write more T-units per composition; consecutive groups write longer T-units, but all of them produce only mid-length T-units. As learners progress, they tend to produce more correct (errorfree) T-units. Both the average number of words per T-unit and the T-unit accuracy ratio show that the more advanced learners become, the longer correct T-units grow, and they produce on average more words per error-free T-unit. In other words, they use more words correctly in Tunits than incorrectly. However, the ratios for W/T and W/EFT are disappointing. The W/T of the better South African learners fall within the 10.18-11.85 range, compared to academic writing that typically contains $20 \mathrm{~W} / \mathrm{T}$. The overall accuracy ratio W/EFT is at the low end. The average of 0.43 is far from the native norm of 0.95 , indicating relatively poor accuracy levels in the second language.

The picture that emerges is not very encouraging. There is clearly room for improvement in both fluency and accuracy. Most learners cannot access sufficient words and structures in a limited time, and they make numerous errors. Spelling also seems to be a problem because, as pointed out above, we could not take spelling errors into account in our analysis. These learners do not seem to be adequately equipped for tertiary study, where academic writing ability is a major requirement. The wide gap between poor and excellent groups is particularly worrying, as both need to follow the same curriculum and write the same examination. We also found that there are learners who border on the illiterate in the matriculation year.

We feel that there are at least three reasons for the poor performance in English of South African learners. First, the teaching of grammar is either neglected or of a poor standard. Formal instruction in grammar, within a communicative framework, has emerged as an acceptable and recommended procedure that can speed up the acquisition of the second language. Second, teachers' own command of grammar may not be of the required standard (cf. Mafisa \& Van der Walt, 2002). Third, teaching and learning in many South African schools is generally of a low standard, as indicated in a recent report of the South African Human Rights Commission (2006).

It is clear that the teaching and the learning of ESL need to be improved, especially that of morphology and syntax in writing. Such an improvement is likely to lead to a general improvement in the fluency and accuracy in writing of ESL learners in South Africa. 


\section{REFERENCES}

BARDOVI-HARLIG, K \& T BOFMAN. 1989. The attainment of syntactic and morphological accuracy by advanced language learners. Studies in Second Language Acquisition, 11:17-34.

BEELD, 8 September 2004:2. Goeie Engels=goeie uitslae.

BEELD, 9 September 2004:16. Taal.

BRUMFIT, CJ. 1984. Communicative methodology in language teaching. Cambridge: Cambridge University Press.

COOPER, TC. 1976. Measuring written syntactic patterns of second language learners. The Journal of Educational Research, 69:176-183.

ELLIS, R. 1994. The study of second language acquisition. Oxford: Oxford University Press.

ENGLERT, CS \& K DUNSMORE. 2007. The role of dialogue in constructing effective literacy settings for students with language and learning disabilities. In Wilkinson, LC \& ER Silliman (Eds), Language and literacy learning in schools. New York: Guilford Press. 201-238

FILLMORE, CJ 1979. On fluency. In Fillmore, CJ, D Kempler \& WSY Wang WSY (Eds), Individual differences in language ability and language behaviour. New York: Academic Press. 85-101.

FULCHER, G. 2003. Testing second language speaking. London: Pearson Longman.

FULCHER, G \& F DAVIDSON. 2007. Language testing and assessment. London: Routledge.

GASS, SM \& L SELINKER. 2001. Second language acquisition: An introductory course. New Jersey: Lawrence Erlbaum.

GRABE, W \& RB KAPLAN. 1997. Theory \& practice of writing. London: Longman.

HARMER, J. 2004. The practice of English language teaching. Edinburgh: Longman.

HATCH, E \& H FARHADY. 1982. Research design and statistics for applied linguistics. Massachusetts: Newbury House.

HAWKEY, R \& F BARKER. 2004. Developing a common scale for the assessment of writing. Assessing Writing 9:122-159. 
HIRANO, K. 1991. The effect of audience on the efficacy of objective measures of EFL proficiency in Japanese university students. Annual Review of English Language Education in Japan, 2:21-30.

HOMBURG, TJ. 1984. Holistic evaluation of ESL compositions: can it be validated objectively? TESOL Quarterly, 18:87-107.

HO-PENG, L. 1983. Using T-unit measures to assess writing proficiency of university ESL students. RECL Journal, 14:35-43.

HUNT, K. 1965. Grammatical structures written at three grade levels. Research Report No.3. Illinois: National Council of Teachers of English.

HUNT, K. 1970. Recent measures in syntactic development. In Lester M (Ed.), Readings in applied transformational grammar. New York: Holt Rinehart. 187-200.

LARSEN-FREEMAN, D. 1978. An ESL index of development. TESOL Quarterly, 12:439- 448.

LARSEN-FREEMAN, D. 1983. Assessing global second language proficiency. In Seliger, HW \& M Long (Eds), Classroom-oriented research in second language acquisition. Massachusetts: Newbury House. 287-304.

LARSEN-FREEMAN, D \& V STROM. 1977. The construction of a second language acquisition index of development. Language Learning, 27:123-134.

LENNON, P. 1990. Investigating fluency in EFL: a quantitative approach. Language Learning, 40:387-417.

LORENZ, G. 1999. Adjective intensification: learners versus native speakers. Amsterdam: Rodopi.

LEE, NI. 2005. An analysis of students' writing at a university in Japan: how do native speakers write differently from international students? [Online] Available url: http://www.aare.edu.an/04pap/lee04483.pdf. [20 January 2007].

MACKEY, A \& S GASS. 2005. Second language research: methodology and design. Mahwah, NJ: Lawrence Erlbaum.

MAFISA, PJ \& JL VAN DER WALT. 2002. Grammatical competence of ESL teachers. Per Linguam 18:15-26.

MILLER, RG. 1981. Simultaneous statistical inference. New York: McGraw Hill.

SAVILLE-TROIKE M. 2006. Introducing second language acquisition. Cambridge: Cambridge University Press. 
SELIGER, HW \& E SHOHAMY. 1989. Second language research methods. Oxford: Oxford University Press.

SOUTH AFRICAN HUMAN RIGHTS COMMISSION. 2006. Report of the public hearing on the right to basic education. Johannesburg: South African Human Rights Commission.

THOMPSON, R. 2003. Writing techniques. [Online] Available url: http://www.tesltimes.com/writing. [4 December 2006].

WOLFE-QUINTERO, K, S INAGAKI \& H KIM. 1998. Second language development in writing: measures of fluency, accuracy and complexity. Manoa: University of Hawai'i.

YAU, M. 1991. The role of language factors in second language writing. In Malave, L \& G Duquette (Eds), Language, culture and cognition: a collection of studies in first and second language acquisition. Clevedon: Multilingual Matters. 266-283.

\section{BIOGRAPHIC NOTE}

Johann L van der Walt is head of the Centre for Academic and Professional Language Practice and Professor of English at the Potchefstroom Campus of North-West University. He specialises in course design, second language teaching, testing and acquisition. Email: Johann.VanderWalt@ nwu.ac.za

Karien Hattingh is a lecturer in English at the Potchefstroom Campus of North-West University. She specialises in second language acquisition and language assessment. 